\begin{tabular}{lr}
\hline PRACE NAUKOWE UNIWERSYTETU EKONOMICZNEGO WE WROCLAWIU \\
RESEARCH PAPERS OF WROCEAW UNIVERSITY OF ECONOMICS & nr 475 2017 \\
\hline Problemy ekonomii, polityki ekonomicznej i finansów publicznych & ISSN $1899-3192$ \\
& e-ISSN $2392-0041$
\end{tabular}

\title{
Mateusz Rolski
}

Uniwersytet Ekonomiczny w Katowicach, Katedra Ekonomii

e-mail: mateusz.rolski@ue.katowice.pl

\section{KSIĄDZ AUGUSTYN SZAMARZEWSKI (1832-1891) - PATRON POLSKIEJ BANKOWOŚCI SPÓLDZIELCZEJ W ZABORZE PRUSKIM}

\section{REV. AUGUSTYN SZAMARZEWSKI (1832-1891) - THE EXPONENT OF POLISH CO-OPERATIVE BANKING IN THE PRUSSIAN PARTITION}

DOI: $10.15611 /$ pn.2017.475.23

JEL Classification: N23

\begin{abstract}
Streszczenie: Niniejszy artykuł koncentruje się na postaci jednego z głównych propagatorów bankowości spółdzielczej w zaborze pruskim - ks. Augustyna Szamarzewskiego. Ks. A. Szamarzewski promował ideę spółdzielczości słowem i czynem, podejmując aktywne działania na rzecz rozwoju spółek pod względem ilościowym, jak również rewidując ich bieżące funkcjonowanie. W bankowości spółdzielczej, która zapewniała tworzenie oszczędności i budowę polskiego kapitału, dostrzegał szansę na wyższy poziom życia dla przyszłych pokoleń. Jego publiczna działalność w postaci tworzenia, reorganizacji i rewizji banków ludowych na wzór instytucji Schulzego dała początek sektorowi, który funkcjonuje w Polsce po dzień dzisiejszy.
\end{abstract}

Słowa kluczowe: ks. Augustyn Szamarzewski, bankowość spółdzielcza w Polsce, spółdzielczość.

Summary: The article concentrates on Rev. Augustyn Szamarzewski - one of the main representatives of Polish co-operative banking in The Prussian Partition. Rev. A. Szamarzewski has promoted the idea of co-operation with the word and deed. He took the action in favour to develop the number of Polish co-operative banks and control their current functioning. He perceived co-operative banking, which collect savings and cumulate Polish funds, as a way to achieve higher quality of life for future generations. He established, reorganised and revised co-operative banks based on Schulze' model. His activity initiated the exceptional part of banking sector that operates until today.

Keywords: Rev. Augustyn Szamarzewski, co-operative banking in Poland. 


\section{Wstęp}

Idea spółdzielczości oszczędnościowo-pożyczkowej na ziemiach polskich narodziła się w okresie zaborów. Kolebką zaś modelu bankowości spółdzielczej był zabór pruski (na wzór systemu Schulzego'). Ludność polska w tym zaborze była poddawana twardej polityce wynaradawiania oraz kolonizacji, popartej znacznym kapitałem niemieckim. Jednocześnie teren zaboru pruskiego był rozwinięty gospodarczo w największym stopniu spośród wszystkich trzech zaborów. Od lat 60. XIX wieku, szczególnie na terenie Wielkopolski, zaczęły powstawać polskie spółki kredytowe, które stały się jedną z form obrony słabszych ekonomicznie Polaków przed, wspieraną dodatkowo przez władze, silniejszą gospodarczo ludnością niemiecką.

Ruch spółdzielczości bankowej był propagowany słowem i czynem przez działaczy społecznych, wśród których znalazł się również ksiądz Augustyn Szamarzewski. W 1859 r. ks. Szamarzewski został wikariuszem w parafii w Środzie Wielkopolskiej - wtedy zaczęła się jego publiczna działalność. Pozostając pod wpływem haseł patriotycznych oraz idei współdziałania jako podstawie pracy organicznej, w $1862 \mathrm{r}$. zainicjował Towarzystwo Rzemieślnicze, czyli Przemysłowe, pod opieką św. Józefa, a następnie został jego prezesem. Organizacja ta zajmowała się kształceniem moralnym i fachowym zrzeszonych rzemieślników, jak również organizacją wspólnych rozrywek. Jeszcze w tym samym roku w ramach towarzystwa, powstał pomysł wzajemnej pomocy pieniężnej, lecz wskutek wybuchu powstania styczniowego Szamarzewski zawiesił pracę nad statutem projektowanej instytucji. Był to jednak dopiero początek prawie trzydziestoletniej aktywnej działalności na rzecz rozwoju polskiej bankowości spółdzielczej, której analiza pozostaje głównym celem badawczym niniejszego artykułu. Metodyka badań wymaga zatem zastosowania metody opisowej oraz analizy źródeł.

\section{Tworzenie i reorganizacja banków ludowych}

Utworzenie kasy oszczędności i pożyczek w Środzie Wielkopolskiej doszło do skutku dopiero na początku 1866 r. Na mocy nowego prawa z 1867 r. kasa przekształciła się w spółkę funkcjonującą na zasadach Schulzego, rozwijając swą działalność i przyjmując wielu członków, także spoza terenu miasta, w którym funkcjonowała. W myśl nowego ustawodawstwa ks. Szamarzewski zapisał spółkę średzką do rejestru handlowego, jako jedną z pierwszych w Wielkopolsce [Dąbrowski 2007, s. 97]. Kasa pozyskiwała środki na działalność pożyczkową w postaci depozytów, lecz opierała się również na udziałach, składkach, ofiarach czy pożyczkach. W ko-

${ }^{1}$ F.H. Schulze był twórcą koncepcji niemieckich banków ludowych, zakładanych przede wszystkim w celu stworzenia członkom możliwości do oszczędzania, a także sposobności udzielania sobie kredytów. Tym sposobem, jak również poprzez wypłaty dywidend od udziałów, spółdzielcy mieli dochodzić do posiadania własnych kapitałów, tworząc klasę średnią [Stefczyk 1914; Ossowski 2001]. 
lejnych latach ks. Szamarzewski przyczynił się do powstania spółek rzemieślniczych w Kostrzynie, Książu i Jarocinie. Propagator spółdzielczości kredytowej spodziewał się odrodzenia ludności nie tylko pod względem gospodarczym, ale również jako wspólnoty społecznej.

W 1871 r. w Poznaniu powstał Związek Spółek Polskich, zwany później Związkiem Spółek Zarobkowych i Gospodarczych na Wielkie Księstwo Poznańskie i Prusy Zachodnie. W obradach, na których powołano związek, uczestniczyło 44 delegatów z 29 spółek, w tym 19 z Wielkiego Księstwa Poznańskiego, 9 z Prus Zachodnich i jeden z Górnego Śląska. Hasło przewodnie sejmiku brzmiało: „Własną pracą i pomocą a siłami zjednoczonymi” [Dąbrowski 2007, s. 111]. Działalność związku miała polegać na pomocy w zakładaniu nowych spółek kredytowych, usprawnianiu działalności już istniejących, organizacji kredytu pomiędzy spółdzielniami, jak również upowszechnianiu idei spółdzielczości ( $\mathrm{w}$ tym m.in. wydawaniu pism). W początkowych latach funkcjonowania związku powstało kilkanaście nowych spółdzielni, jednakże trend ten został zahamowany przez kryzys gospodarczy panujący w Niemczech. Ponadto spółkom brakowało wykwalifikowanej kadry, do czego w znacznym stopniu przyczyniała się antypolska polityka władz pruskich. W $1873 \mathrm{r}$. istniało w zaborze pruskim 68 spółdzielni pożyczkowych - zarówno należących do związku, jak i funkcjonujących poza nim [Inglot (red.) 1971, s. 95].

Spółki kredytowe funkcjonujące na terenie zaboru pruskiego nie od początku wykazywały działania oparte na zasadach solidarności. Większe i silniejsze stroniły od związku jako instytucji, według nich, zbędnej. Spółki słabsze ekonomicznie oraz potrzebujące wsparcia organizacyjnego i moralnego nie mogły z kolei same stanowić podpory silnego związku stowarzyszającego. Przetrwanie organizacji oraz jej rozwój mogła zapewnić jedynie osoba charyzmatyczna, całkowicie oddana sprawom związkowym. Pierwszym patronem ${ }^{2}$ organizacji został Kazimierz Kantak, kolejnym Kazimierz Szulc, jednak obaj piastowali to stanowisko po kilka miesięcy. Dopiero trzeci z mianowanych - ks. Augustyn Szamarzewski - od 1872 r. rozpoczą właściwą aktywność patronacką̧ . Pierwszych kilka lat patron poświęcił na reorganizację spółek zarówno należących, jak i nienależących do związku. Często podróżował do instytucji, gdzie dokonywał rewizji ich funkcjonowania. Do zadań patrona miało należeć m.in. udzielanie porad w prowadzeniu ksiąg rachunkowych, pomoc prawna czy kontrola przestrzegania zasad spółdzielczych. Związek Spółek nieustannie podejmował działania w celu powiększania liczby instytucji stowarzyszonych ${ }^{4}$.

\footnotetext{
${ }^{2}$ Władza wykonawcza związku składała się z dwóch instytucji: komitetu oraz patrona, który był jednocześnie jego przewodniczącym. Następnie obie funkcje rozdzielono.

${ }^{3}$ Choć sam był początkowo przeciwnikiem Związku. Według niego nadmierna „opieka” raczej hamowała niż wspierała rozwój spółek.

${ }^{4}$ Jedną z prób była odezwa do spółek nienależących do związku, która podkreślała korzyści materialne i moralne kurateli związku i patrona. W wyniku odezwy kilka spółek przystąpiło, kilka innych zaś obiecało przystąpić [Szamarzewski 1882, s. IV-V].
} 
Źródła wskazują, że dzieło ks. Szamarzewskiego było rzeczywistą pracą organiczną. Reorganizował bowiem spółki od podstaw - począwszy od porządkowania rachunkowości, nauki załatwiania spraw sądowych, relacji kredytowych pomiędzy spółką a członkami po czynny udział w zebraniach zarządów, rad nadzorczych czy zgromadzeniach członków. Jednym z celów nadrzędnych patrona pozostawało wykształcenie jednolitego typu banku ludowego przygotowanego do samodzielnej działalności depozytowo-kredytowej [Ochociński 1965, s. 85 i nast.]. W kwestiach moralnych patron niejednokrotnie piętnował nadmierne oprocentowanie pożyczek, a tym samym dążenie do wypłacania wysokich dywidend, jako działania przeciwko ubogim członkom spółek. Praktyki te traktował jako typowo kapitalistyczne dążenie do zysku, niemające nic wspólnego z ideą spółdzielczości. Ks. Szamarzewski podkreślał, że zadaniem spółek jest postaranie się o pozyskanie taniego pieniądza oraz udzielanie kredytów członkom przy niskim oprocentowaniu [Tomaszewski 1912, s. 55]. Surowo oceniał autokratyczne dążenia zarządów oraz brak możliwości kontroli działań kasjerów przekonanych o swej nieomylności ${ }^{5}$. Zachęcał rady nadzorcze do częstszych kontroli zarządu i ogólnego stanu finansowego spółek. Jak mówił: „Rada nadzorcza - to suma ustaw, jest to duch towarzystwa, który wiać powinien zawsze i wszędzie przy wszystkich czynnościach. Rada nadzorcza jest wentylem bezpieczeństwa przy całej maszynerii społecznej, którą są zawsze spółki” [Kusztelan 1918, s. 26]. Podkreślał, że celem działalności instytucji spółek kredytowych jest stworzenie podstaw finansowych dla rozwoju handlu i rzemiosła, a nie realizacja osobistych interesów osób zarządzających spółdzielniami. Starał się zaszczepić ideę spółdzielczości w spółkach, ucząc na jednej z rewizji cierpliwego postępowania wobec członków nieobeznanych z procesem przyznawania kredytów. Mówił: „Gdy chodzi o udzielanie kredytu, bądźmy cierpliwi, gdy wniosek o pożyczkę nam wręczają, bądźmy cierpliwi, gdy mimo naszego thumaczenia nie rozumieją biegu i porządku kasowego, objaśniajmy ich, aż nie pojmą sprawy, bądźmy chętni, usłużni, nie każmy uboższym członkom stać za drzwiami” [Kusztelan 1918, s. 27]. Ks. Szamarzewski nadał niewątpliwie stanowisku patrona nowy styl pracy, charakteryzujący się m.in. systematyczną wizytacją terenową. Osobiste rewizje pozwalały na bieżąco doskonalić organizację spółek oraz dokonywać oceny ich działalności pod względem realizacji dyrektyw związku (które na bieżąco przekazywał komitetowi głównemu) [Dąbrowski 2007, s. 136]. Badacze podkreślają, że „Szamarzewski jako patron dokonał wielkiego dzieła. Niejednokrotnie przebywał w jednej spółdzielni po kilka tygodni, by uczyć członków i zarząd rachunkowości i dobrego gospodarowania w spółdzielni” [Gójski, Marszałek 1968, s. 42]. Krzewienie idei spółdzielczości oszczędnościowo-pożyczkowej oraz jej ujednolicanie poprzez tworzenie systemu

\footnotetext{
${ }^{5}$ Sprawozdanie Związku Spółek za 1881 r. wskazuje przykład braku kasowego w towarzystwie pożyczkowym dla miasta Kłecka i okolicy, wobec kasjera zaś prowadzone było śledztwo. Patron miał odtąd nagłaśniać wszelkie rozpoznane nieprawidłowości i przedstawiać je na posiedzeniu właściwej rady nadzorczej [Szamarzewski 1882, s. III-IV].
} 
spółek widoczne było również w kwestii nazewnictwa - często instytucje te mianowały się bankami ludowymi, zamiast kasami, towarzystwami czy stowarzyszeniami.

W swojej pracy u podstaw ks. Szamarzewski niejednokrotnie spotykał się z oporem spółek rewidowanych, który ujawniał się dopiero po wyjeździe patrona. Instytucje te nie były bowiem zobligowane do stosowania się do wskazówek ideowych czy wdrażania dokumentów i instrukcji przez niego dostarczanych. Nawet w jednym ze sprawozdań Związku Spółek wpływ patronatu na spółki określono wyłącznie jako informacyjny i moralny [Szamarzewski 1879, s. II]. Patronowi zarzucano m.in. bezwzględne wywieranie wpływu na decyzje walnego zgromadzenia, jak również głoszenie idei utylitaryzmu czy materializmu [Dąbrowski 2007, s. 146]. Nie dysponując żadnymi instrumentami o charakterze sankcyjnym, ks. A. Szamarzewski piętnował błędy władz poszczególnych spółdzielni w sporządzanych przez siebie sprawozdaniach. Innym problemem, z którym musiał się zmierzyć, był permanentny brak środków do prowadzenia działalności patronackiej. Często spółki należące do związku nie regulowały bowiem należności składkowych ${ }^{6}$.

Równolegle z działaniami reorganizacyjnymi ks. A. Szamarzewski był inicjatorem zakładania nowych instytucji oszczędnościowo-pożyczkowych. W pierwszym roku urzędowania patrona powstało z jego ramienia, według różnych statystyk, od 18 do 22 spółek, lecz w pięciu kolejnych latach (1874-1879) utworzono ich zaledwie 15. Jako główny powód spadku liczby zakładanych spółdzielni podaje się niedostatek ludzi odpowiednio wykształconych i przygotowanych do pełnienia funkcji kierowniczych. Patron zdawał sobie sprawę, że sama chęć, inicjatywa społeczeństwa lokalnego nie pozwoli na trwałe funkcjonowanie spółki bez podstawy w postaci wykwalifikowanej kadry. Mówił: „Nie dziwcie się, panowie, że nie kwapię się z zakładaniem nowych spółek. Trzy, cztery dni na miejscu uczyłem zarządy, uregulowałem wszystko, a po dwóch latach dawny nieład i dzika gospodarka (...) Bo dobry zarząd błogie skutki wywiera, a opieszały ruiny sprowadza" [Kusztelan 1918, s. 36-37]. Ks. Szamarzewski miał świadomość, że nie będzie w stanie przyciągnąć do spółek ludzi oddanych idei i codziennej pracy na rzecz rozwoju banków ludowych bez odpowiedniego wynagrodzenia. Kwestia ta nie została jednak zaaprobowana wśród spółdzielców. Szczególnie po 1875 r. do rozwoju spółek przyczyniło się za to duchowieństwo, coraz częściej zasiadające w zarządach i radach nadzorczych. Wzorcową zaś instytucją spółdzielczości ludowej pod względem organizacji administracji i rachunkowości była spółka w Środzie Wielkopolskiej (Spółka Średzka), w której ks. Szamarzewski pełnił funkcję prezesa do $1883 \mathrm{r}$.

Patron zakładał nowe spółki na wzór banków ludowych systemu Schulzego. Pierwotnie rozwijał spółdzielczość oszczędnościowo-pożyczkową wśród ludności miejskiej, głównie rzemieślników. Z czasem jednak do spółek zaczęło należeć coraz więcej mieszkańców terenów wiejskich. Powszechność członkostwa była znacznym

\footnotetext{
${ }^{6} \mathrm{Na}$ co wskazują sprawozdania związku. Na przykład sprawozdanie za $1891 \mathrm{r}$. wskazuje nawet na kilka spółek, których zaległości sięgają aż 1880 r. [Kusztelan 1892, s. XXIV].
} 
odejściem od zasad wzorcowych, co uczyniło system polskich spółek pożyczkowych oryginalnym, wynikającym z rodzimych potrzeb, zadowalającym ks. Szamarzewskiego [Kosik 1992, s. 33]. Innymi cechami swoistego „polskiego modelu spółek" było uspołecznienie zysku w niepodzielnym funduszu rezerwowym oraz w postaci dywidendy nieprzekraczającej procentu od depozytów, udzielanie kredytów wyłącznie członkom czy zrzeszanie jednostek słabych gospodarczo [Ochociński 1965, s. 44]. Ze względu na potrzeby włościan patron radził zabiegi w postaci obniżania procentów, wydłużania terminów pożyczek czy rezygnacji z zabezpieczenia wekslowego. Postulował składki członkowskie pobierane z części zysków spółki na utrzymanie administracji, aby odciążyć pożyczkobiorców, a także ochronić fundusz rezerwowy, który niejednokrotnie był wykorzystywany na cele pokrycia kosztów administracyjnych. Ponadto wyznawał zasadę współodpowiedzialności wszystkich członków zarządu za sprawy spółki.

\section{Silne zrzeszenie i centrala finansowa jako podstawowe elementy rozwoju systemu bankowości spółdzielczej}

Zasługi ks. Szamarzewskiego dla spółdzielczości oszczędnościowo-pożyczkowej nie sprowadzały się tylko do reorganizacji czy zakładania nowych banków ludowych. Jako patron związku już od 1872 r. czynnie uczestniczył w pracach nad powołaniem Banku Włościańskiego jako centrali finansowej dla spółdzielni kredytowych. Oponował przeciwko poglądom Mieczysława Łyskowskiego, który najpierw stał na czele banku, następnie zaś pełnił funkcję członka rady nadzorczej (był również przewodniczącym komitetu Związku Spółek). Łyskowski proponował, aby spółki stały się agenturami (oddziałami) Banku Włościańskiego, a kasjerzy płatnymi agentami, zatem instytucje spółdzielcze miały niejako pośredniczyć w interesach centrali finansowej. Szamarzewski nie zgadzał się na te warunki, mając świadomość, że wpływały one na ograniczanie autonomii spółek oraz koncentrowały się wyłącznie na interesie Banku Włościańskiego. Nie uwzględniały natomiast realizacji podstawowych postulatów spółek - możliwości uzyskania niskooprocentowanych kredytów oraz korzystnego lokowania wolnych środków pieniężnych [Dąbrowski 2007, s. 122]. Spór trwał kilka lat. Ostatecznie banki ludowe otrzymały dowolność w wyborze instytucji, w której chciały zaciągnąć kredyty, zaś Bank Włościański stał się niejako bankiem partnerskim. Zasługą patrona w tym względzie była działalność na rzecz instytucji spółdzielczych, często młodych i niedoświadczonych, aby już na początku nie stały na niekorzystnej pozycji względem większej, potencjalnej centrali finansowej. Ks. Szamarzewski, stając się odtąd pośrednikiem pomiędzy Bankiem Włościańskim a spółkami, wykorzystywał instrument kredytu do reorganizacji poszczególnych banków ludowych. Kiedy spółka zwracała się do patrona, otrzymywała potrzebne środki, jednak pod warunkiem poddania się rewizji oraz zastosowania się do rad i wskazówek Szamarzewskiego w kwestiach rachunkowych czy prawnych [Kusztelan 1918, s. 46-61]. 
Wszystkie powyższe działania propagatora spółdzielczości oszczędnościowo-pożyczkowej prowadziły do wyraźnego rozwoju sektora. W latach 1879-1880 liczba banków ludowych zrzeszonych w związku wynosiła 48. W 1878 r. na 85 istniejących instytucji spółdzielczych tego rodzaju w Księstwie Poznańskim i Prusach Zachodnich 45 utrzymywało relacje finansowe z Bankiem Włościańskim. Ks. Szamarzewski dostrzegał rezultaty rozwoju: ,Widocznem jest, że umiejętniej zaczynamy prowadzić nasze interesa, że w martwych na pozór cyfrach naszych Spółek działa niezłomny duch pracy, uzbrojony w męstwo i wytrwałość i siłę zachowawczą, chcący żyć przy ognisku własnem" [Kusztelan 1918, s. 65-66].

Wszystkie lata, w których ks. Szamarzewski pracował jako patron Związku Spółek, przebiegały również pod znakiem prób różnego rodzaju reform w organizacji. Dyskusja nad ich kształtem koncentrowała się wokół kompetencji komitetu i patrona jako organów wykonawczych związku . Szczególne tarcia odbywały się na tym polu po $1880 \mathrm{r}$. pomiędzy nim a wspomnianym już Mieczysławem Łyskowskim, który postulował ograniczenie zakresu działań patrona oraz wzmocnienie pozycji komitetu (a nawet zastąpienie stanowiska patrona przez przewodniczącego komitetu). Ks. Szamarzewski stanął przed dylematem odejścia ze stanowiska, poprzez które stał się rozpoznawalny jako propagator ludowej spółdzielczości oszczędnościowo-pożyczkowej. W sprawozdaniu za 1882 r. przyznał, że spółki potrzebują stałej pomocy i nadzoru, praca zaś na rzecz rozwoju całego ruchu jest ponad siły jednego człowieka [Szamarzewski 1883, s. V]. W związku z tym w 1883 r. zaproponował przekazanie kompetencji patrona w ręce komitetu oraz rewizorów [Kusztelan 1901, s. 172-173]. Na sejmiku w Trzemiesznie miało miejsce emocjonalne wystąpienie ks. Piotra Wawrzyniaka (późniejszego następcy ks. A. Szamarzewskiego na stanowisku patrona), który w imieniu spółek zaapelował o pozostawienie funkcji patrona oraz o pozostanie ks. Szamarzewskiego na tym stanowisku. Rozumiejąc sytuację niemożliwości pełnienia rewizji spółek przez jedną osobę, zaproponował powołanie rewizorów wskazywanych przez komitet i patrona, którzy mieli składać sprawozdania z kontroli organom Związku Spółek. Ks. Szamarzewski miał odpowiedzieć: „Mam nadzieję w Bogu, że zdołam sprostać zadaniu Patronatu, jeżeli przyznacie mi pomoc przez Komisję proponowaną, a w takich warunkach pragnę $\mathrm{z}$ wami pracować do końca. Zostaję Patronem!" [Kusztelan 1918, s. 107]. Tym sposobem demokratyczny zryw w postaci oddolnej inicjatywy spółek usankcjonował silną pozycję dotychczasowego patrona w strukturach związku i publicznie podkreślił jego nieocenione zasługi dla rozwoju spółdzielczości oszczędnościowo-pożyczkowej.

\footnotetext{
${ }^{7}$ Zakres obowiązków patrona był ustalony zgodnie z regulacjami wewnętrznymi związku. Należało do nich m.in. rozpowszechnianie idei spółdzielczości kredytowej (tworzenie spółek), wizytacje i rewizje, prowadzenie statystyk, redagowanie wydawnictw związku, wykonywanie uchwal sejmików oraz postanowień komitetu. Patron nie mógł jednak podejmować indywidualnych inicjatyw oraz stosować sankcji bez zgody komitetu, który był de facto instytucją nadrzędną. Podkreśla się, że funkcjonowanie tego rodzaju dwuwładzy było rozwiązaniem niefortunnym ze szkodą dla patrona, który miał styczność z realną działalnością spółek [Dąbrowski 2007, s. 169-170].
} 
Jednym z najważniejszych przedsięwzięć Związku Spółek w latach 80. XIX wieku było utworzenie centrali finansowej dla banków ludowych. Roli takiej nie odgrywał Bank Włościański, ponieważ jego relacje ze spółkami miały dobrowolny charakter. Po wielu dyskusjach i próbach znalezienia właściwego projektu ${ }^{8} \mathrm{w}$ grudniu 1885 r. podpisano założycielski akt notarialny Banku Związku Spółek Gospodarczych i Zarobkowych. Początkowy kapitał nowej instytucji był niewielki, jednak od 1887 r. (sejmik w Gnieźnie) spółki zaczęły nabywać akcje banku, przekazując na ten cel minimum 10\% swojego majątku (funduszu rezerwowego i udziałów). W $1888 \mathrm{r}$. spośród 61 spółek należących do związku udziały w banku posiadało $55 \mathrm{z}$ nich. Do banków ludowych należało łącznie nieco ponad $60 \%$ kapitału zakładowego Banku Związku Spółek [Kusztelan 1918, s. 131]. Zasługi ks. Szamarzewskiego w utworzeniu centrali finansowej sprowadzały się zarówno do propozycji rozwiązań organizacyjno-prawnych ${ }^{9}$, poszukiwań pierwszych udziałowców, jak i wspierania swoim autorytetem nowej idei instytucji spółdzielczych. Patron Związku zostawał jednocześnie kuratorem Banku Związku Spółek, przez co łączył obie instytucje. Zadaniem patrona było pośrednictwo pomiędzy interesami banku a interesami spółek. W ramach kurateli patron sprawdzał czynności zarządu oraz kwestie rachunkowe, w razie nieprawidłowości zaś informował o tym radę nadzorczą.

W kolejnych latach okazało się, że Bank Związku Spółek spełniał postulaty zrzeszonych w nim banków ludowych, pod względem zarówno depozytowym, jak i kredytowym. Powstanie banku spowodowało wzrost liczby spółek należących do związku. Centrala finansowa spowodowała ponadto umocnienie całego systemu banków ludowych na terenie zaboru pruskiego. Sprawozdanie Związku Spółek za 1891 r. wskazuje, że udziały w banku posiadały 63 spółki na 86 przynależących do związku [Kusztelan 1892, s. XXXII].

Od września 1886 r. patron Szamarzewski zaczął usuwać się w cień pracy spółdzielczej. Z jednej strony, ze względu na nową, liczną parafię w Ostrowie, gdzie poświęcał się pracy duszpasterskiej. Z drugiej - ks. Szamarzewski miał świadomość, że do głosu w coraz większym stopniu zaczynają dochodzić jego następcy z ks. Piotrem Wawrzyniakiem na czele ${ }^{10}$. Ze względu na podobne poglądy i zaangażowanie w pracę na rzecz spółek patron nie obawiał się o przyszłość bankowego ruchu spółdzielczego.

\footnotetext{
${ }^{8}$ Kwestie te zostały przekazane do dyskusji na Komitecie Głównym zgodnie z rezolucjami sejmików w Toruniu (1882 r.) i Trzemiesznie (1883 r.). W 1884 r. na jednym z posiedzeń komitetu zgodzono się co do faktu, że instytucją taką nie może być żadna ze spółek, lecz osobna instytucja finansowa [Szamarzewski 1884, s. V].

${ }^{9} \mathrm{~W}$ grudniu 1883 r. ks. Szamarzewski złożył projekt umowy banku oparty na prawie akcyjnym [Szamarzewski 1884, s. X].

${ }^{10}$ Ks. Piotr Wawrzyniak został wicepatronem związku w 1887 r. Ks. A. Szamarzewski przekazał dużą część swoich zadań przewodniczącemu związku - Kusztelanowi (statystyka, korespondencja ze spółkami itd.) oraz ks. Wawrzyniakowi (rewizje w spółkach, nadzór nad rewizorami). Nadal jednak np. uczestniczył w sejmikach czy w posiedzeniach komitetu związku.
} 
Propagator spółdzielczości kredytowej na terenie Wielkiego Księstwa Poznańskiego i Prus Zachodnich umarł 8 maja 1891 roku.

\section{Praca na rzecz spółek jako dobro najwyższe}

Na postać księdza Augustyna Szamarzewskiego należy z pewnością patrzeć przez pryzmat społecznika, który dużą część swojego życia poświęcił na pracę u podstaw. Nie pomagała mu w tym rola duszpasterza, którą kojarzono raczej z posługą w parafii, mistycyzmem czy ascetyzmem. Ks. Szamarzewski wyszedł poza ówczesny, standardowy obraz osoby duchownej, jego działalność zaś należy postrzegać jako nowatorską. Patron często podkreślał jednak, że działalność na polu społecznym jest dla niego drugorzędna (zaraz za kapłaństwem). Co istotne, a niespotykane ks. Szamarzewski przez lata pełnił funkcję patrona pro publico bono, nie pobierając wynagrodzenia (z wyjątkiem delegacji), niejednokrotnie pokrywając koszty funkcjonowania instytucji patrona $\mathrm{z}$ własnych środków.

W sprawozdaniu przedstawionym na sejmiku w 1875 r. patron napisał: „Cała zagadka naszego położenia będzie rozwiązana, jeśli nie będziemy się łudzić i pojmiemy, że w epoce miedzi żyjemy, gdy będziemy umieli gospodarować miedziakami. Małymi to kapitalikami musi nasz świat pracować, przywrócić sobie byt, mienie, stanowisko i znaczenie (...) Ten program gospodarowania miedziakami postanowiły sobie spółki. Właśnie spółek jest to właściwością, w ich to organizacji leży natchnąć społeczeństwo wspólną oszczędnością i wspólną potrzebą gromadzenia grosza, z zachowaniem nieco z zebranych zysków na podniesienie i utrzymanie instytucji i spowodować i usposobić do długowiekowej a skutecznej pracy" [Dąbrowski 2007, s. 150]. Cytat ten bodaj w najlepszy sposób oddaje sens pracy organicznej ks. Szamarzewskiego, który zdawał sobie sprawę z trudnej sytuacji gospodarczej ludności polskiej w zaborze pruskim. Jego idea koncentrowała się na tym, aby za pomocą gromadzenia drobnych oszczędności - tych „małych kapitalików”, wzajemnej integracji i niestrudzonej pracy przekazać następnym pokoleniom drogę do osiągnięcia wyższego poziomu życia. Wskazywał on kierunek rozwoju spółdzielczości bankom ludowym. Wiedział, że praca przyniesie efekty, lecz dopiero w perspektywie długoterminowej: „Zadanie wielkie, zadanie wiekowe, bo drobny nasz grosz, jak krople w naszych rzekach ma się wspólnemi siłami zlać w wielki prąd, aby nigdy nie przestał nazywać się prądem" [Kusztelan 1918, s. 80]. Co istotne - patron popierał rozwiązanie w postaci nieograniczonej odpowiedzialności członków za zobowiązania spółek [Kosik 1992, s. 13]. Szamarzewski był zatem propagatorem współdziałania, tworzenia wspólnot wspierających się wzajemnie w budowaniu kapitału, a jednocześnie odpowiadających całym swoim majątkiem.

Patron propagował pracę na rzecz społeczności lokalnej w postaci wzajemnego wsparcia w zakresie finansowym (tworzenie spółek) oraz moralnym. Tworzenie silnych organizacji gospodarczo-społecznych, jak również gromadzenie kapitału miało z kolei umacniać naród. Działalność patrona trzeba zatem rozpatrywać w kontekście 
historycznym - trudnej sytuacji Polaków w zaborze pruskim, dyskryminowanych i poddawanych germanizacji ${ }^{11}$. Budowa podstaw finansowych w społeczeństwie polskim, a w konsekwencji rozwój handlu, rzemiosła i rolnictwa, miały pomóc w konkurencji na polu gospodarczym z zaborcą niemieckim oraz społecznością żydowską [Dąbrowski 2007, s. 107]. Potrafił przemawiać w sposób budzący szacunek oraz motywujący do wspólnych działań, co potwierdzają ówcześni badacze [Kusztelan 1918, s. 28]. Sekretarz rady nadzorczej Spółki Średzkiej - dr Ignacy Opieliński w przemówieniu na sejmiku w Środzie Wielkopolskiej w październiku 1891 r. podkreślił trzy kwestie, dzięki którym spółka ta zawdzięczała pomyślny rozwój. Jako pierwszą wskazał sumienność i bezinteresowność pracy zarządu, który funkcjonując według przepisów, nie narażał spółki na niepotrzebne ryzyko. Drugim z czynników była właściwa działalność rewizyjna rady nadzorczej, która stała się dla spółki gwarantem zaufania publicznego. Trzecim, nieocenionym elementem była działalność ks. Szamarzewskiego, który prostował wszelkie nieprawidłowości, dawał nieustanne wskazówki, poprawiał statuty czy wprowadził wzorowe książki kasowe. Dr Opieliński w następujących słowach odniósł się do jego postaci: „Jakikolwiek sąd wyda potomność o działalności ś.p. X Augustyna Sz., to każdy mu przyznać będzie zniewolony, że był to mąż poświęcenia i wielkiego serca, mąż rzadkiej inicjatywy, umiejący budzić życie obumarłe i zagrzewać ostygłych i obojętnych, mąż, mający wszędzie i zawsze dobro publiczne na celu. A już to Spółki (...), których on właściwie jest ojcem, a które tak ważną i doniosłą w stosunkach naszych odgrywają rolę, jego jednego niezaprzeczoną i niespożytą na zawsze pozostaną zasługą; Spółkami wystawił sobie pomnik od spiżu trwalszy i zasłużył na wdzięczność późnych pokoleń. (...) przez Spółki społeczeństwo nasze (...) nauczył zmysłu oszczędności (...) dodał ufności w siły własne i zasoby własne" [Kusztelan 1892, s. VIII].

Za najważniejszą uważał jednak czynną działalność. Jak powiedział: „Praca moja w spółkach bardziej umoralnia niż wszystkie moje kazania” [Kusztelan 1918, s. 41]. Zwieńczenie pracy ks. Szamarzewskiego w najlepszy sposób ukazują zatem dane dotyczące spółek: w sprawozdaniu za 1891 r. w Wielkim Księstwie Poznańskim i Prusach Zachodnich do związku należało 86 spółek (sprawozdanie obejmowało również dwie spółki powstałe w 1892 r.), liczba zaś członków w 78 z nich ${ }^{12}$ wyniosła 27671 [Kusztelan 1892, s. XXIX-XXXIV].

\footnotetext{
${ }^{11}$ Władze pruskie chciały również w jak największym stopniu kontrolować działalność spółek. W jednym ze sprawozdań związku widnieje informacja o nakazie sądowym rozesłanym przez sądy okręgowe niektórym spółkom dotyczącym m.in. konieczności spisywania protokołów z walnych zebrań czy uskuteczniania ogłoszeń w języku niemieckim jako języku urzędowym. Związek uznał postanowienie jako nieprawne i zalecał spółkom składanie zażaleń do ministra sprawiedliwości lub w razie niepowodzenia inne rozwiązania [Szamarzewski 1884, s. V].

1278 spółek przysłało sprawozdania dotyczące liczby członków.
} 


\section{Zakończenie}

Charakter działalności i determinacja trzeciego z kolei, lecz pierwszego prawdziwego patrona Związku Spółek Zarobkowych i Gospodarczych spowodowała wzrost liczby polskich spółek kredytowych funkcjonujących w zaborze pruskim. Głównym celem ks. Augustyna Szamarzewskiego była popularyzacja idei spółdzielczości bankowej oraz stałe udoskonalanie funkcjonowania banków ludowych. To właśnie we współdziałaniu widział drogę dla podniesienia materialnego i duchowego polskiej ludności ciemiężonej przez zaborcę. Jego niezłomność w głoszonych poglądach i nauce udzielanej młodym spółdzielcom budzi ogromny podziw i szacunek.

Sektor bankowości spółdzielczej na ziemiach polskich od początku swojego istnienia po czasy współczesne przeszedł zasadnicze przemiany związane z funkcjonowaniem w różnych systemach gospodarczych i warunkach politycznych. Obecnie również podlega on przekształceniom instytucjonalnym (System Ochrony Instytucjonalnej lub zrzeszenie zintegrowane). Banki ludowe tworzone w drugiej połowie XIX wieku według modelu Schulzego niejednokrotnie funkcjonują po dzień dzisiejszy jako nowoczesne banki spółdzielcze zdolne konkurować w obecnych realiach rynkowych, skoncentrowanych na zaspokajaniu coraz wyższych wymagań klientów. Ks. A. Szamarzewski był zatem propagatorem idei ponadczasowej, działalności opartej na oddolnej potrzebie i inicjatywie społecznej, która doczekała się godnych następców.

\section{Literatura}

Dąbrowski R., 2007, Ksiądz Augustyn Szamarzewski (1832-1891), Wydawnictwo Poznańskie, Poznań. Gójski J., Marszałek L., 1968, Spółdzielczość: zarys rozwoju historycznego, Zakład Wydawnictw CRS, Warszawa.

Inglot S. (red.), 1971, Zarys historii polskiego ruchu spółdzielczego do 1918 r. Cz. I, Zakład Wydawnictw CRS, Warszawa.

Kosik J., 1992, O spótkach Ks. Augustyna Szamarzewskiego pod zaborem pruskim w latach 1872-1891, Wydawnictwo Uniwersytetu Wrocławskiego, Wrocław.

Kusztelan J., 1892, Dwudzieste sprawozdanie Zwiazku Polskich Spótek Zarobkowych i Gospodarczych w W. Księstwie Poznańskiem i w Prusach Zachodnich za rok 1891, Nakładem Patronatu Ogólnego Związku Polskich Spółek Zarobkowych i Gospodarczych, Poznań.

Kusztelan J., 1901, Kilka uwag o organizacji i rozwoju spótek polskich pod panowaniem pruskiem, Poznań.

Kusztelan R., 1918, Ks. Patron Augustyn Szamarzewski: pionier spólnictwa ludowego. Przyczynek do historji spółek polskich pod zaborem pruskim, Poznań.

Ochociński S., 1965, Podstawy i zasady wielkopolskiej spółdzielczości kredytowej do roku 1918, Wydawnictwo Poznańskiego Oddziału PTE, Poznań.

Ossowski J., 2001, Spółdzielczość w wybranych systemach filozoficznych i ekonomicznych, Pieniądze i Więź, nr 2.

Stefczyk F., 1914, O spółkach oszczędności i pożyczek systemu A.F.W. Raiffeisena, Lwów. 
Szamarzewski A., 1879, Siódme sprawozdanie Związku Spółek Zarobkowych w Prusach Zachodnich, W. X. Poznańskiem i na Górnym Śląsku. Rok 1878, Nakładem Związku Spółek Zarobkowych, Poznań.

Szamarzewski A., 1882, Dziesiąte sprawozdanie Związku Spółek Zarobkowych w Prusach Zachodnich, W. X. Poznańskiem i na Górnym Śląsku. Rok 1881, Nakładem Związku Spółek Zarobkowych, Poznań.

Szamarzewski A., 1883, Jedenaste sprawozdanie Związku Spółek Zarobkowych w Prusach Zachodnich, W. X. Poznańskiem i na Górnym Śląsku. Rok 1882, Nakładem Związku Spółek Zarobkowych, Poznań.

Szamarzewski A., 1884, Dwunaste sprawozdanie Związu Spółek Zarobkowych w Prusach Zachodnich, W. X. Poznańskiem. Rok 1883, Nakładem Związku Spółek Zarobkowych, Poznań.

Tomaszewski W., 1912, Pół wieku polskich spółek zarobkowych i gospodarczych w W. Ks. Poznańskiem, Prusach Zachodnich i na Górnym Śląsku. Ich powstanie, organizacja i rozwój od r. 1861-1910. Tom I, nakładem autora, Poznań. 